IFAC-TSRR vol. 3 (2011) 97-109

\title{
Diffuse-light absorption spectroscopy for beer classification and prediction of alcoholic content
}

\author{
Leonardo Ciaccheri $\left({ }^{1}\right)$, Edgar Eugenio Samano Baca $\left({ }^{2}\right)$, \\ Heidi Ottevaere $\left({ }^{2}\right)$, and Anna Grazia Mignani $\left({ }^{1}\right)$
}

$\left({ }^{1}\right) \quad$ IFAC-CNR, Via Madonna del Piano 10, 50019 Sesto Fiorentino (FI), Italy

$\left(^{2}\right) \quad$ Vrije Universiteit Brussel, Faculty of Engineering Science, Department of Applied Physics and Photonics, Brussels - Belgium 


\section{Introduction}

This report summarizes the results obtained during a spectroscopy experiment which was carried out at the "Fiber Optic and Microoptic Sensors Laboratory" of CNR IFAC, during the month of July 2011, as a part of Edgar Samano’s internship.

The scope of the experiment was:

1. To perform spectroscopic measurements on selected samples of beer by means of an innovative fiber optic instrumentation - that is diffuse-light absorption spectroscopy in the visible and near-infrared bands performed by means of an integrating sphere.

2. To perform turbidity and refractive index measurements by means of conventional instruments.

3. To process the measured data, aiming to highlight whether a correlation to quality indicators is possible, and to what extent.

A selection of Belgian beers was provided by Vrije Universiteit Brussel, and other beers were purchased in an Italian supermarket.

Appendix 1 summarizes the entire beer collection, together with the country of origin, the code assigned for a quick identification, the brand, the alcoholic content, as well as the class. In fact, according to what declared on the bottle - which was the only information available - the beers were preliminary classified according to the fermentation method (Lager, Ale, Lambic, ...), to color (Golden, Dark, ....), and to wheat content (Weiss). Therefore, the class can be considered as a beer identity, which is potentially useful for authentication or fraud detection.

In addition to spectroscopy measurements, conventional turbidity and refractive measurements were also performed, so as to add more information potentially useful for identifying the beer peculiarity.

During the Edgar Samano’s internship, other two spectroscopic experiments were carried out:

a. Scattered colorimetry - that is absorption spectroscopy in the visible band, performed at four angles $\left(0^{\circ}, 30^{\circ}, 60^{\circ}\right.$, and $\left.90^{\circ}\right)$ with respect to the line of sight.

b. Fluorescence spectroscopy - that is $90^{\circ}$ fluorescence spectroscopy with excitation provided by an LED emitting at $365 \mathrm{~nm}$, and detection in the visible band.

However, since they did not add any appreciable improvement to discrimination results or to correlation to quality indicators, they will not be considered in this report.

MATLAB ${ }^{\circledR}$ codes, suitably written for processing the experimental data here presented, were used.

Section 2 describes the setup for diffuse-light absorption spectroscopy and the results obtained. Section 3 presents the results of turbidity and refractive index measurements. Section 4 describes the prediction of the alcoholic content. Section 5 shows the beer classification method and results. Section 6 comes to conclusion and perspectives. 


\section{Diffuse-light absorption spectroscopy - setup and results}

When carrying out absorption spectroscopy in liquids by means of transmission measurements, the results are found to be influenced by dispersed scattering particles that cause turbidity. In fact, the detected signal is spuriously amplitude modulated when particles settle down, or change their position in time.

Diffuse-light absorption spectroscopy, that is, spectroscopy carried out by means of an integrating cavity, is a valid alternative for overcoming the scattering-dependent aspects ${ }^{1,2}$. As shown in Figure 1 , diffuselight absorption spectroscopy makes use of an integrating cavity that contains the sample under test. The source and the detector are butt-coupled to the cavity. Almost all the light shining on the cavity surface is diffusely reflected, and the detector can be placed on the cavity surface in order to gather the average flux. By introducing in the cavity an absorbing medium, a reduction of the radiance in the sphere occurs. Apart from opto-geometrical factors, the reduction is related only to the absorption of the medium and its volume, and is independent of nonabsorbing objects within it, such as suspended scattering particles. Diffuse-light absorption spectroscopy has been used for biological application, for water and gas analysis as well as for the analysis of edible liquids, namely the extra virgin olive oil $3,4,5,6$.

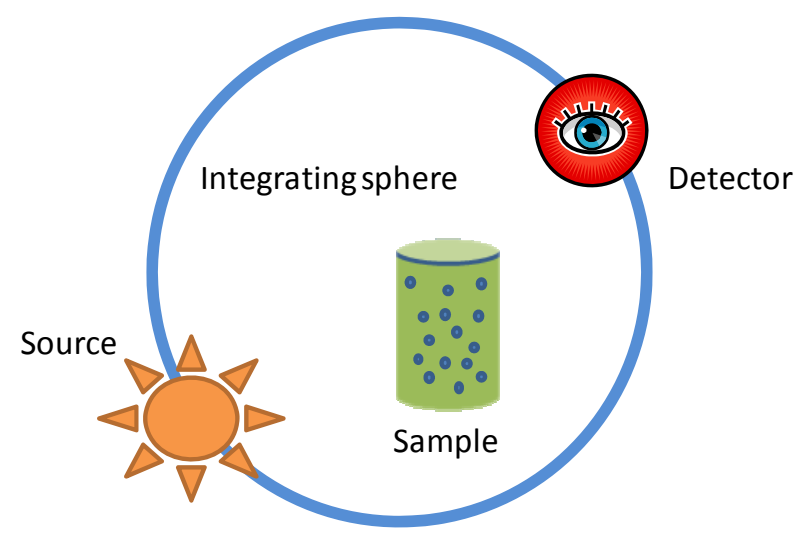

Fig. 1 - Scheme of diffuse-light absorption spectroscopy

An innovative experimental setup was used, as sketched in Figure 2. It consisted of a custom-made integrating sphere compatible to insertion of a glass vial containing the beer under test. The integrating sphere was equipped by means of a 100W halogen source for illumination and an SMA-compatible port for detection by means of an optical fiber coupled to a compact fiber optic spectrometer. Two spectrometric detectors were used, for visible and near-infrared measurements, respectively. The same optical fiber was used for detection, which was alternately connected to the spectrometers. Table I summarizes the optoelectronic components used in the experimental setup.

Figure 3 shows the practical implementation of the setup for diffuse-light absorption spectroscopy. The picture shows the integrating sphere with the lamp power supply at its right, while at the left side only the fiber optic spectrometer for near-infrared measurements is shown.

\footnotetext{
${ }^{1}$ P. Elterman, “Integrating cavity spectroscopy”, Applied Optics, vol. 9, 1970, pp. 2140-2142.

${ }^{2}$ E.S. Fry, G.W. Kattawar, R.M. Pope, “Integrating cavity absorption meter”, Appled Optics, vol. 31, 1992, pp. 2055-2065.

${ }^{3}$ M.N. Merzlyak, K.R. Naqvi, “On recording the true absorption spectrum and the scattering spectrum of a turbid sample: application to cell suspensions of the cyanobacterium Anabaena variabilis, Journal of Photochemistry and Photobiology B: Biology, vol. 58, 2000, pp. 123-129.

${ }^{4}$ I. Fetch, M. Johnson, "Non-contact, scattering-independent water absorption measurement using a falling stream and integrating sphere”, Measurement, Science and Technology, vol. 10, 1992, pp. 612-618.

${ }^{5}$ E. Hawe, C. Fitzpatrick, P. Chambers, G. Dooly, E. Lewis, "Hazardous gas detection using an integrating sphere as a multipass gas absorption cell”, Sensors and Actuators A, vol. 141, 2008, pp. 414-421.

${ }^{6}$ A.G. Mignani, L. Ciaccheri, H. Ottevaere, H. Thienpont, L. Conte, M. Marega, A. Cichelli, C. Attilio, A. Cimato, "Visible and near-infrared absorption spectroscopy by an integrating sphere and optical fibers for quantifying and discriminating the adulteration of extra virgin olive oil from Tuscany”, Analytical \& Bioanalytical Chemistry, vol. 399, 2011, pp. 1315-1324.
} 

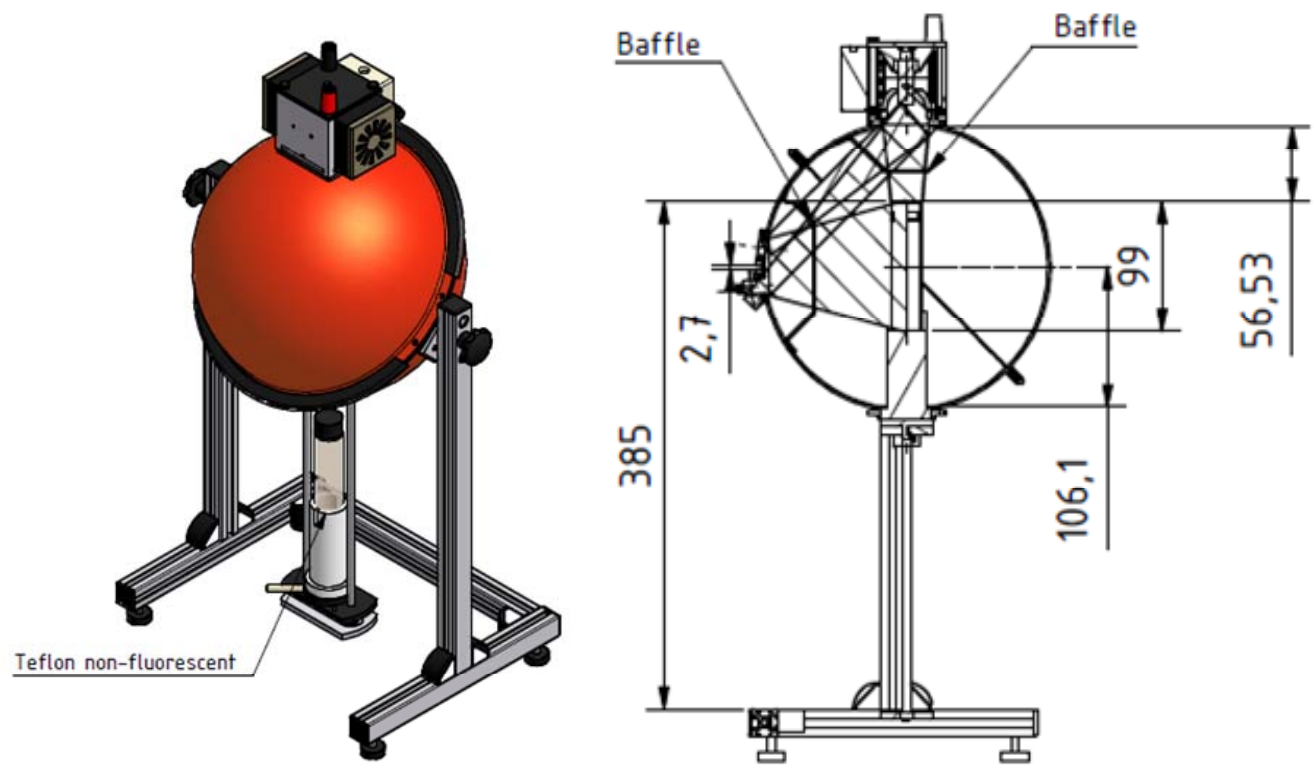

Fig.2 - Drawings of the custom-made integrating sphere used for diffuse-light absorption spectroscopy of beers

Tab. 1 - Optoelectronic components used in the diffuse-light absorption spectroscopy setup

\begin{tabular}{|l|l|}
\hline Component & Model \\
\hline Integrating sphere & GigaOptik, custom model \#ISP-21-ILP-056 \\
\hline Source & Osram 100W halogen lamp \\
\hline Detector for the visible band & Ocean Optics USB4000 \\
\hline Detector for the near-infrared band & Bayspec SuperGamut NIRS-0900-1700-SMA \\
\hline Optical fiber & All silica, core/clad diameter: 50/125 $\mu \mathrm{m}$ \\
\hline Glass vial & Fisher scientific, TUL-520-081S, volume $28,25 \mathrm{ml}$ \\
\hline
\end{tabular}

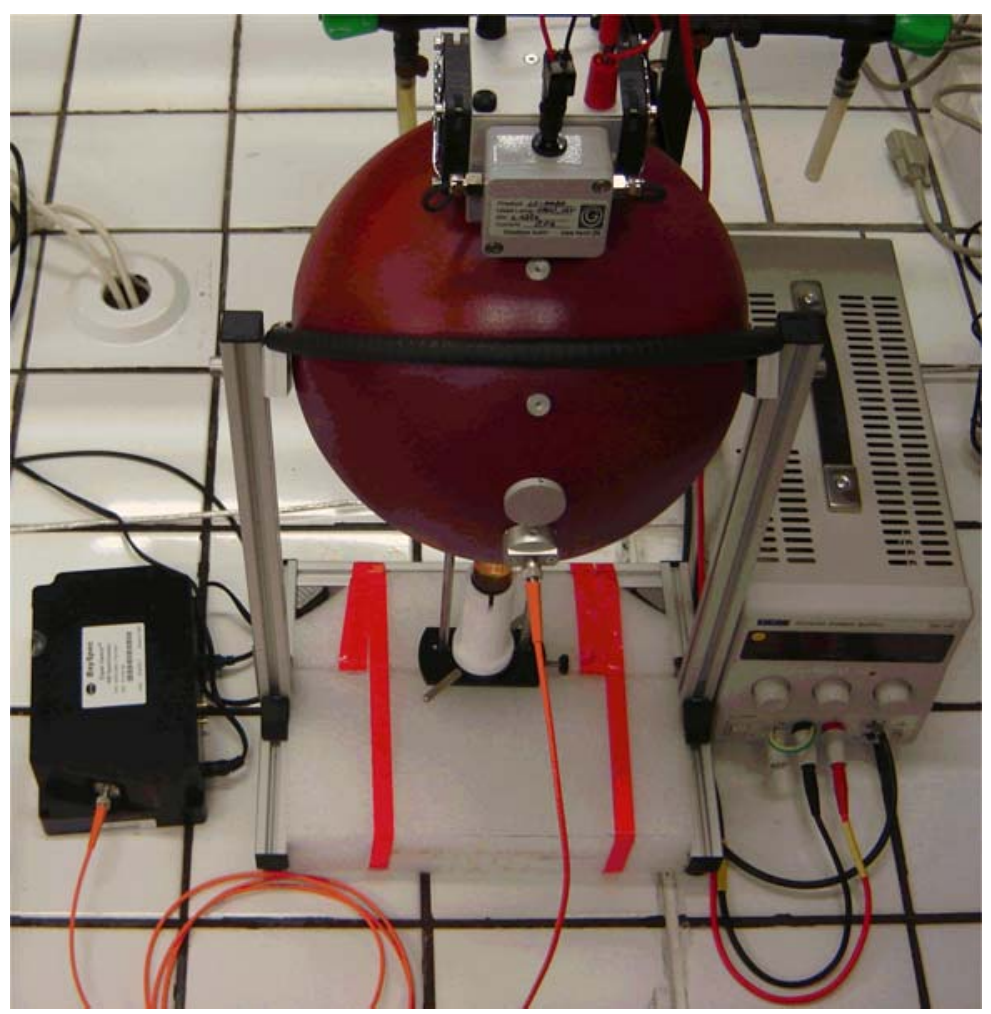

Fig. 3 - Practical implementation of the diffuse-light absorption spectroscopy setup 
A sample of each beer was used to fully fill a glass vial. The following test-rig was used as absorption measurement protocol:

- $\quad$ absorbance was computed as: $A=-\log _{10} \frac{I}{I_{0}}$.

- $\quad I$ and $I_{0}$ were the light intensities diffused by the integrating sphere, measured by the optical fiber.

- $\quad I_{0}$ was measured by inserting in the sphere an empty vial prior to each beer sample measurement.

- $\quad$ I was measured by inserting in the sphere the glass vial containing the beer sample.

Figure 4 shows typical diffuse-light $I_{0}$ spectra measured in the visible and near-infrared bands. They take into account source spectrum, sphere diffusivity, optical fiber absorption, as well as the spectrometer sensitivities.

The results of diffuse-light absorption spectroscopy experiment of the entire beer collection are shown in Figure 5. The first-derivative spectra were considered for NIR representation, since this further processing provided a better spectra discrimination.
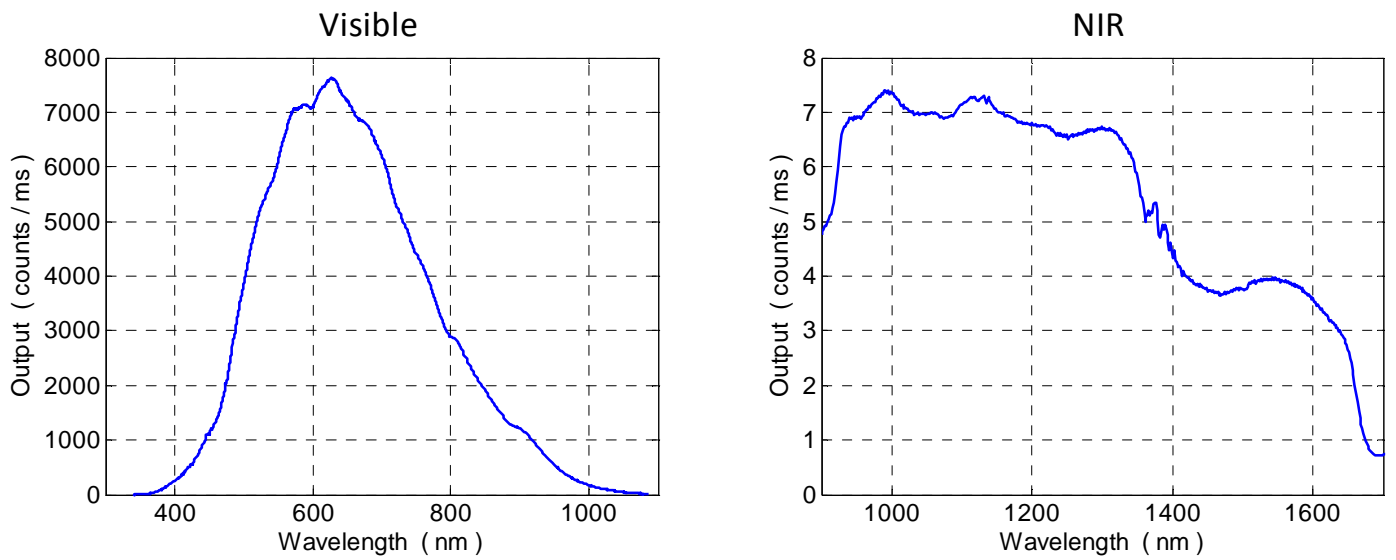

Fig. 4 - Typical diffuse-light absorption spectra in the visible (left) and near-infrared (right) bands used as reference
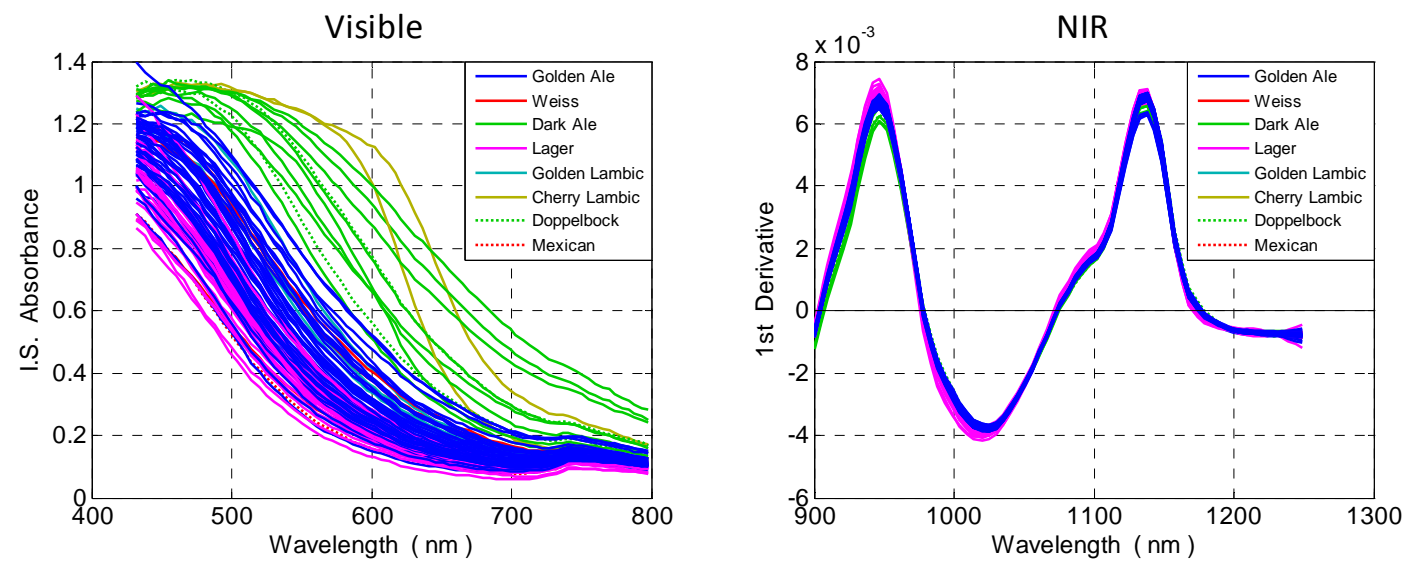

Fig. 5 - Results of the diffuse-light absorption spectroscopy experiment: visible spectra (left), and first-derivative near-infrared spectra (right) of the entire beer collection 


\section{Turbidity and refractive index measurements - instruments and results}

Beer turbidity and refractive index were also measured, since they certainly are peculiar parameters contributing to identify the beer character. They were measured by means of commercially available instruments:

- $\quad$ Hach 2100 P turbidimeter.

- $\quad$ Atago R-5000 Abbe refractometer.

Turbidity and refractive index measured values of the entire beer collection are listed in Appendix 1.

The distribution of refractive index values can be represented by the histogram of Figure 6, the skewness of which was 1.1 .

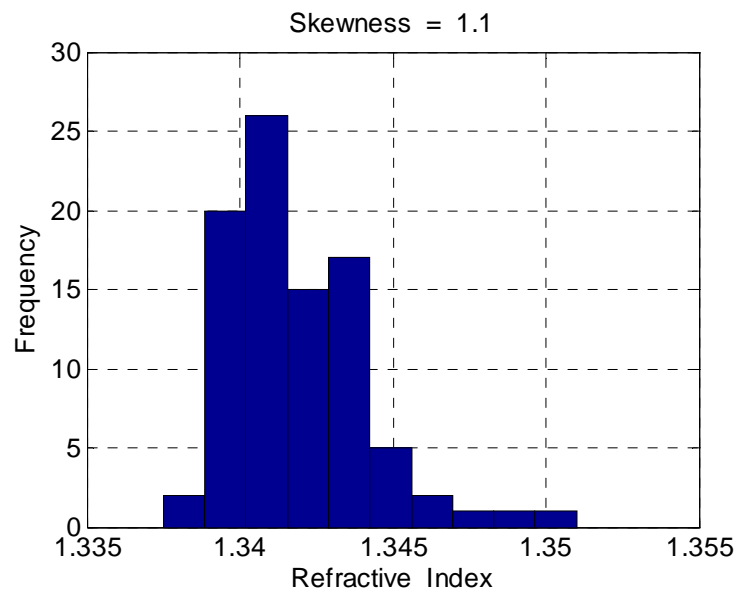

Fig. 6 - Results of refractive index measurements

The distribution of turbidity values can be represented by the histograms of Figure 7-left. The skewness of turbidity distribution is 3.28 - a pretty high value - since the turbidity of most beers was lower than 100 NTU. By considering the decimal logarithm of turbidity, a lower skewness was obtained, that was 0.23 , as shown in Figure 7-right.
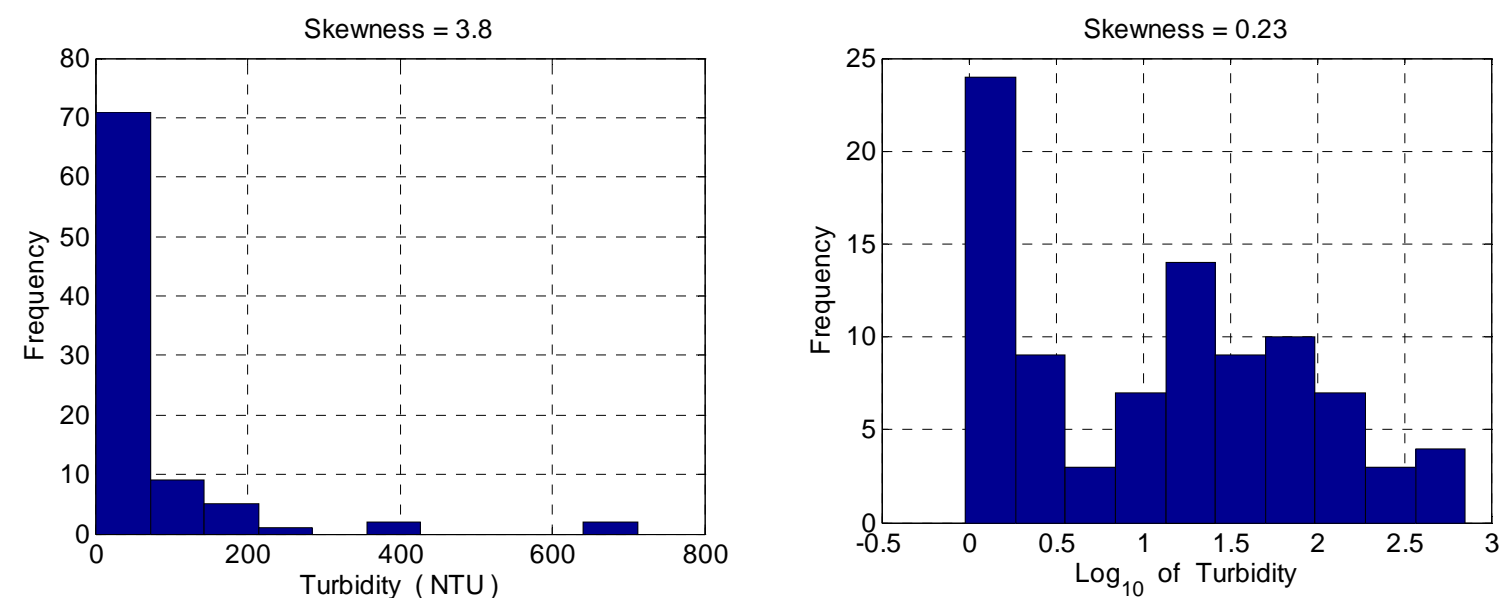

Fig. 7 - Results of turbidity measurements: distribution of turbidity values (left), and distribution of logarithm of turbidity values (right) 


\section{Prediction of alcoholic content}

A quality indicator of the beer is the alcoholic content. An attempt of prediction was carried out by means of a Partial Least Squares regression (PLS) of near-infrared spectra. In fact, the ethanol content is usually detected - spectroscopically - by means of near-infrared measurements ${ }^{7,8,9}$, and PLS is one of the most popular techniques for the prediction of quantitative variables in a multicomponent mixture ${ }^{10}$.

Figure 8 shows the results of PLS processing of near-infrared spectra for alcoholic content prediction. Figure 8-left shows the calibration model, which considered 48 randomly sorted beers, while Figure 8-right shows the validation model, which considered the other 38 beers. These results were achieved by means of 2 PLS factors. Table 2 summarizes the results of PLS processing.
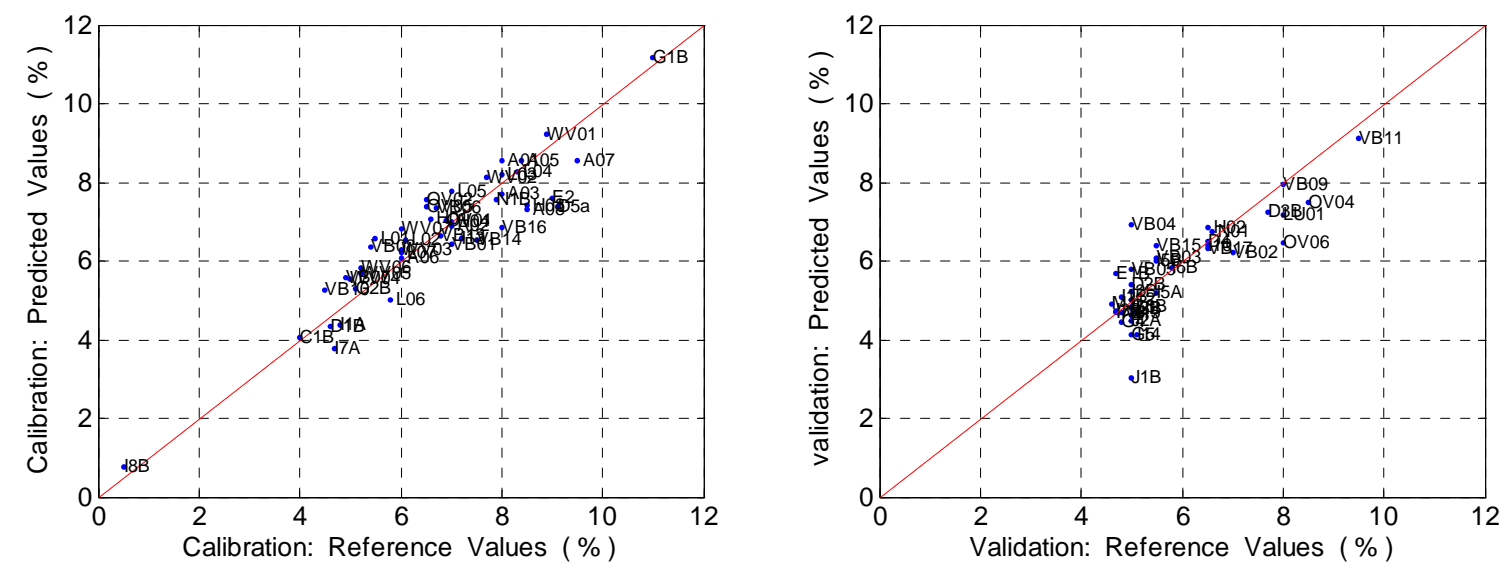

Fig. 8 - Prediction of alcoholic content by means of PLS processing of near-infrared spectra: calibration model (left), and validation model (right)

Tab. 2 - Summary of PLS regression coefficients, and their meaning

\begin{tabular}{|l|l|l|}
\hline Coefficient & Value & Meaning \\
\hline $\mathrm{R}^{2}$ & 0.848 & $\begin{array}{l}\text { It is the squared correlation coefficients between predicted and reference values, for the } \\
\text { calibration set - the fit is as better as this value is closer to } 1\left(\mathrm{R}^{2} \leq 1\right)\end{array}$ \\
\hline RMSEC & 0.7 & $\begin{array}{l}\text { It is the Root Mean Square Error of Calibration, and represents the spread of calibration } \\
\text { points along the target line - the fit is as better as this value is closer to zero }\end{array}$ \\
\hline RMSEP & 0.7 & $\begin{array}{l}\text { It is the Root Mean Square Error of Validation, and represents the spread of validation } \\
\text { points along the target line - the fit is as better as this value is closer to zero; also, the } \\
\text { calibration/validation model is as better as RMSEC and RMSEP are closer }\end{array}$ \\
\hline
\end{tabular}

In practice, this model allows to predict the alcoholic content of beer \#n by measuring the diffuse-light absorption spectrum, and by using Equation 1:

\footnotetext{
${ }^{7}$ B.R. Buchanan, D.E. Honigs, C.J. Lee, W. Roth, "Detection of ethanol in wines using optical-fiber measurements and nearinfrared analysis”, Applied Spectroscopy, vol. 42, 1988, pp. 1106-1111.

${ }^{8}$ P. Tipparat, S. Lapanantnoppakhun, J. Jakmunee, K. Grudpan, "Determination of ethanol in liquor by near-infrared spectrophotometry with flow injection”, Talanta, vol. 53, 2001, pp. 1199-1204.

${ }^{9}$ M.J.C. Pontes, S.R.B. Santos, M.C.U. Araujo, L.F. Almeida, R.A.C. Lima, E.N. Gaiao, U.T.C.P. Souto, “Classification of distilled alcoholic beverages and verification of adulteration by mear infrared spectrometry", Food Reserach International, vol. 39, 2006, pp. 182-189.

${ }^{10}$ S. Wold, M. Sjöström, L. Erikkson, "PLS-regression: a basic tool for chemometrics", Chemometrics and Intelligent Laboratory Systems, vol. 58, 2001, pp. 109-130.
} 


$$
\hat{y}_{n}=\sum_{m=1}^{M} r_{m} x_{n m}
$$

where:

- $\quad \mathrm{M}=$ number of predicting variables - that are the wavelengths.

- $\quad r_{m}=$ regression coefficient of the m-wavelength, as shown in Figure 9.

- $\quad \mathrm{x}_{\mathrm{n} \mathrm{m}}=$ value of absorbance at $\mathrm{m}$-wavelength of \#n beer.

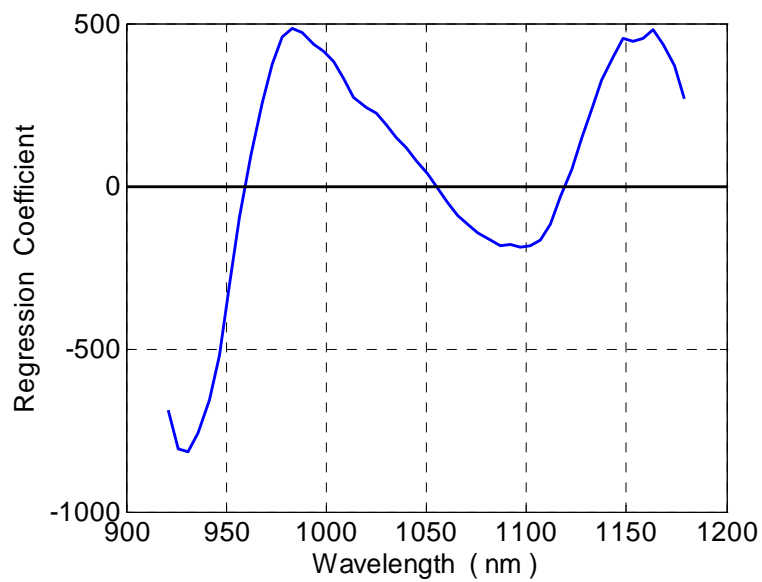

Fig. 9 -Regression coefficients used in Equation 1 for predicting the alcoholic content as a function of wavelength

\section{Beer classification according to class}

Beer clustering according to class may be interesting for authentication purposes. In order to achieve this result, a data matrix was built up by merging the experimental data which were intuitively correlated to the beer identity. Then, the data matrix was processed by means of Principal Component Analysis (PCA), which is one of the most popular methods for object classification ${ }^{11}$.

\subsection{Data Matrix}

An 86 x 6 matrix was created, by considering as peculiar information of each beer identity 6 variables:

1. $\quad$ TURB $=\log _{10}$ (turbidity).

2. $\quad$ IND $=$ refractive index.

3. $\quad \mathrm{NIR}=0.5 \mathrm{D}_{1}(930 \mathrm{~nm})+0.33 \mathrm{D}_{1}(980 \mathrm{~nm})+0.17 \mathrm{D}_{1}(1150 \mathrm{~nm})$

- where $D_{1}(\lambda)$ was the first derivative of near-infrared spectrum at the specified wavelength

- note that NIR is a peculiar beer information, since the selected wavelengths corresponded to the best regression coefficients of Figure 9

- in practice, the NIR function gave a good approximation of alcoholic content, as shown in Figure 10.

\footnotetext{
${ }^{11}$ J.E. Jackson, A User's Guide to Principal Components, 2003, J. Wiley \& Sons Inc., Hoboken.
} 


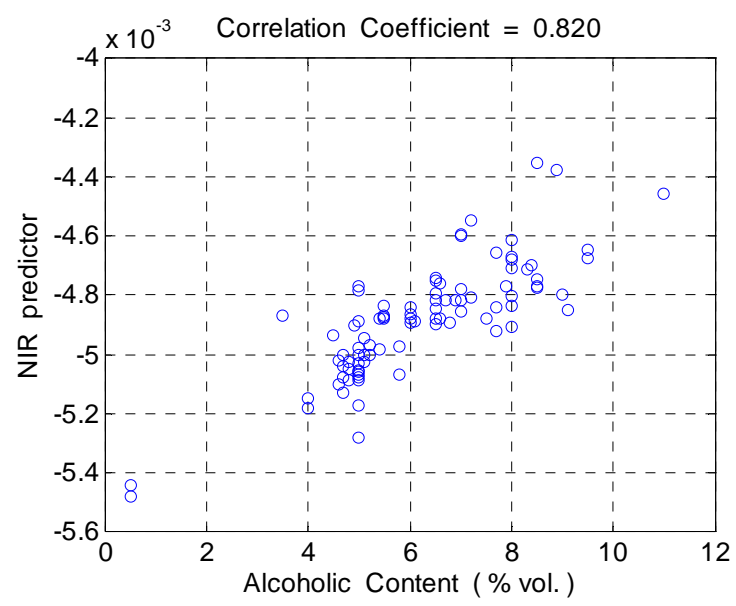

Fig. 10 - NIR function as best fit of alcoholic content prediction

Since the beer color is another peculiar identity, the tri-chromatic coordinates - X, Y, Z - were computed from the visible spectra. $\mathrm{X}, \mathrm{Y}, \mathrm{Z}$ were referred to the measurement with the empty vial; therefore, they express the color-distance of the beer sample from the transparency of the vial. These color-correlated variables were considered in the data matrix:

4. $\mathrm{Y}$ : as it is, which represented the luminance - Figure 11-left plots the behavior of $\mathrm{Y}$ as a function of beer type, showing the darker beers having lower luminance (Cherry Lambic, Dark Ale, and Doppelbock) at the plot bottom, while the lighter having higher luminance (Golden Ale, Golden Lambic, and Lager) at the plot top.

5. $\mathrm{X}=\mathrm{X} /(\mathrm{X}+\mathrm{Y}+\mathrm{Z})$.

6. $\mathrm{z}=\mathrm{Z} /(\mathrm{X}+\mathrm{Y}+\mathrm{Z})-$ as shown in Figure 11-right, the chromatic $(\mathrm{x}-\mathrm{z})$ plane correctly represents the beer distribution according to color, as a U-shaped curve with Golden Ale types (the lighter and less colored) at the vertex.

7.
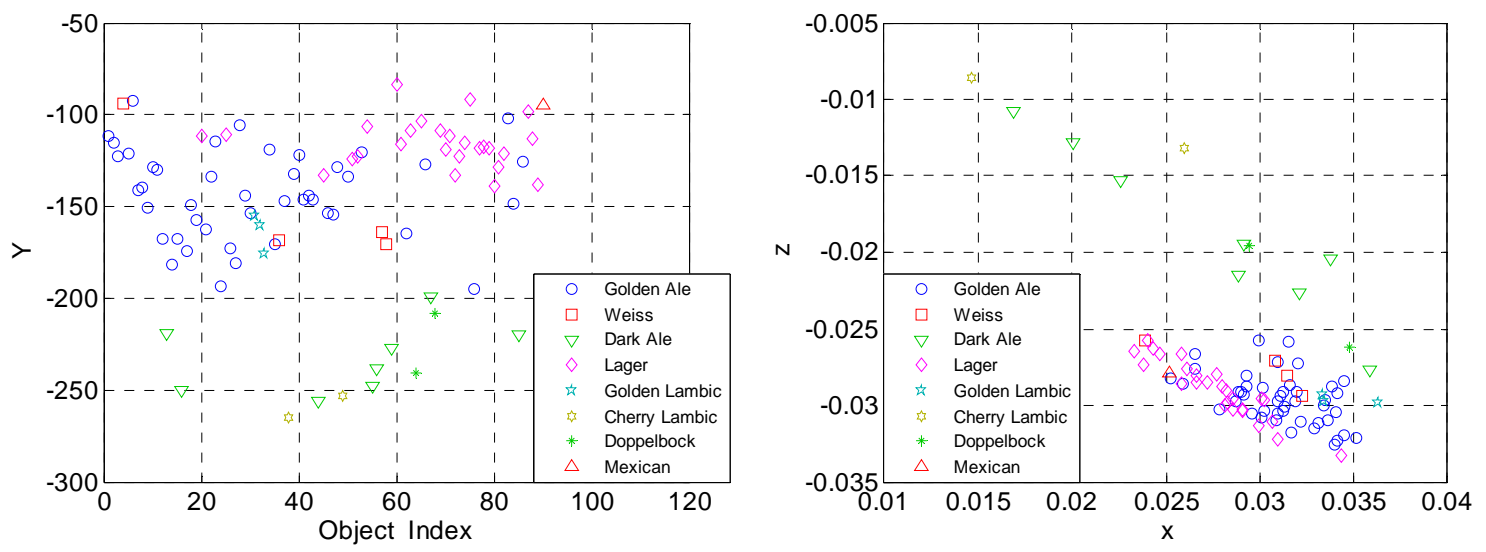

Fig. 11 - Luminance Y behavior (left), and (x-z) chromatic plane for beer color representation 


\subsection{PCA processing}

Figure 12 shows the results PCA processing of data matrix. The first three PC components were considered, and their plots are given in the PC1-PC2 and PC1-PC3 planes. Top figures show the score-loadings biplots, where scores and loadings are scaled in order to allow the simultaneous representation of samples and variables on the same plot. Samples are represented as points, while variables are represented as vectors emanating from origin and indicating the direction in which the corresponding variable increases. Bottom figures show the score plots only, for a straightforward interpretation of results.
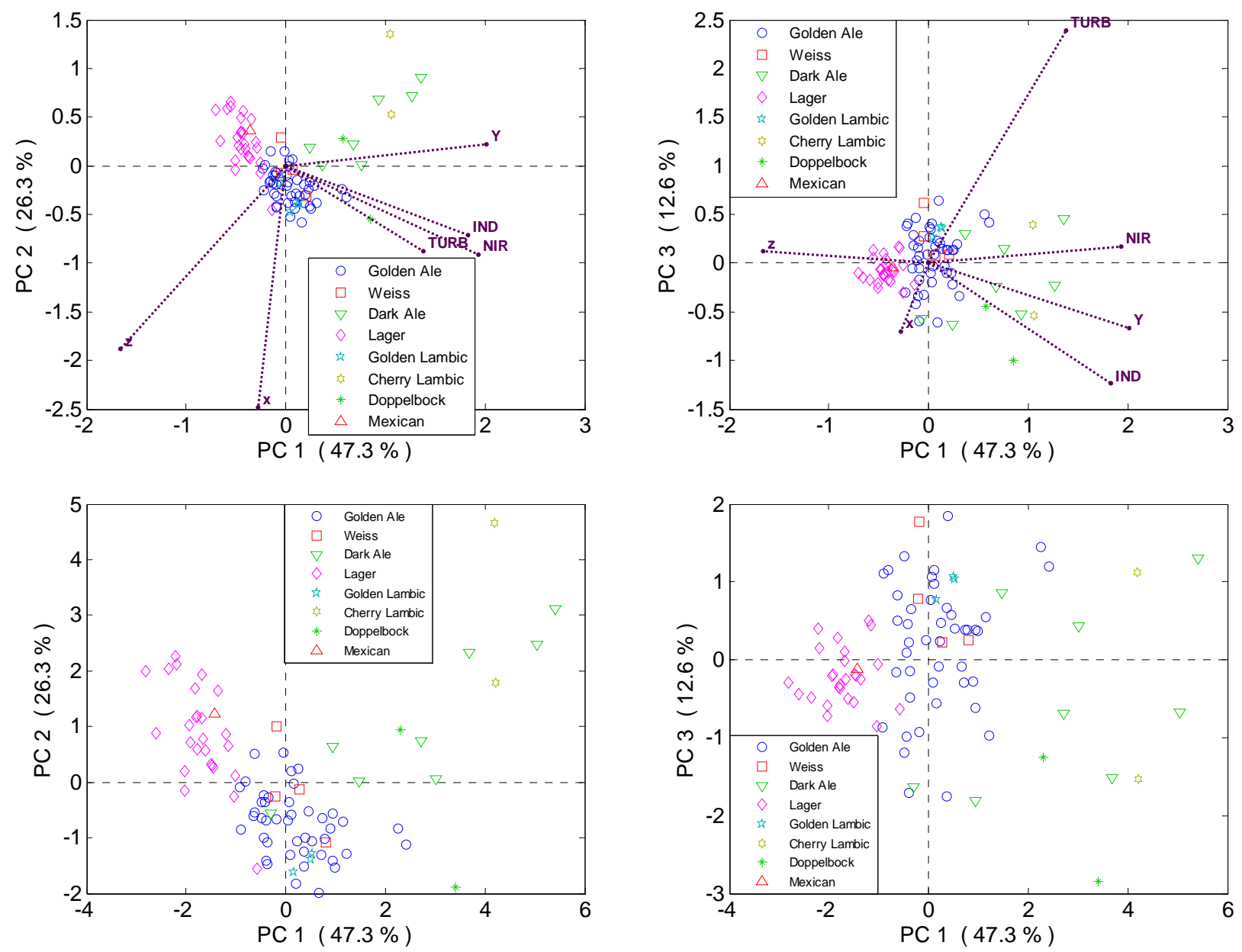

Fig. 12 - Beer clustering according to class in the PC1-PC2 (left) and PC1-PC3 planes (right); score-loading biplots (top) and score plots (bottom)

- $\quad$ The PC1-PC2 plane, which explains $73.6 \%$ of total variance, discriminate quite well the Lager beers, the Golden Ales and the Dark Ales:

- Lager and Golden Ales are separated along the bisecant of II and IV quadrants. Main contributions to this splitting come from IND and NIR, due to the higher alcoholic content of Ales. TURB contributes strongly too, because many Belgian Ales are bottle conditioned and contain sediments.

- From the point of view of chromaticity, Golden Ales have slightly stronger x and Y, reflecting their slightly darker color, while $\mathrm{z}$ is about the same for both classes.

- The discrimination between Dark and Golden Ales is along the bisecant of I and II quadrants. This splitting is mainly chromatic in nature wit red beer having stronger $\mathrm{Y}$ and weaker $\mathrm{z}$ and $\mathrm{y}$. NIR, IND and TURB are similar to that of Golden Ales.

- Weiss beers and Golden Lambic cannot be separated from Golden Ales, while the Mexican beer is mixed with the Lagers.

- $\quad$ The PC1-PC3 plane is also much informative: 
- In fact, the PC1-PC2 plane represents quite well $\mathrm{z}$ and NIR, moderately well $\mathrm{x}$ and $\mathrm{Y}$, but do not give a good representation of IND and, above all, TURB.

- Indeed, TURB is the main contributor to PC3.

- The divergence of IND from NIR reflects the fact that refractive index is not determined exclusively by alcohol. The beers pointing towards IND in the PC1-PC3 plane are dark, and this suggests that IND-interfering substances are more abundant in these beers.

- This view shows also that Weiss and Golden Lambic beers are high in turbidity, but not high enough to split them from Ales.

Other comments:

- Weiss beers are indeed similar to Ale beers because they are usually top-fermenting beers. Moreover, Weiss beers are never $100 \%$ wheat (wheat percentage is about $50 \%$ ), and some Ale beers also contain wheat. The distinction between Weiss and Ale beers is a matter of wheat percentage ${ }^{12}$.

- The Corona Mexican beer is classified as "pale lager" - it is therefore logic that it lies in the same classification area of the maps.

\section{Conclusions and perspectives}

A library of 86 beers was considered. They were produced in different countries by means of different ingredients and fermentation methods. All beers were spectroscopically characterized by means of an innovative setup for diffuse-light absorption spectroscopy, which provided a scattering-free spectroscopic fingerpring of beers in the visible and near-infrared bands. In addition, standard turbidity and refractive index measurements were performed. These data were processed by means of a multivariate data analysis looking for highlighting the beer peculiarity and character.

The capability to predict the alcoholic content by means of near-infrared spectra processing was the first encouraging result achieved. This result is precursor of online continuous monitoring of the alcoholic content during fabrication, by means of a flow-compatible device as shown in Figure 13.

The fusion of scattering-free optical data which included a color information - that is the visible absorption spectrum - together with turbidity and refractive index values made it possible to achieve a good clustering according to the beer class. This class was created by taking into account the peculiar beer characteristics such as color, fermentation method, alcoholic content and wheat content.

These preliminary results are promising: they represent a first attempt for correlating optical data to beer quality indicators. The availability of a library of certified beers, will make it possible to test how a correlation of optical and certification data exists and to what extent, towards a full-optical monitoring of beer process production.

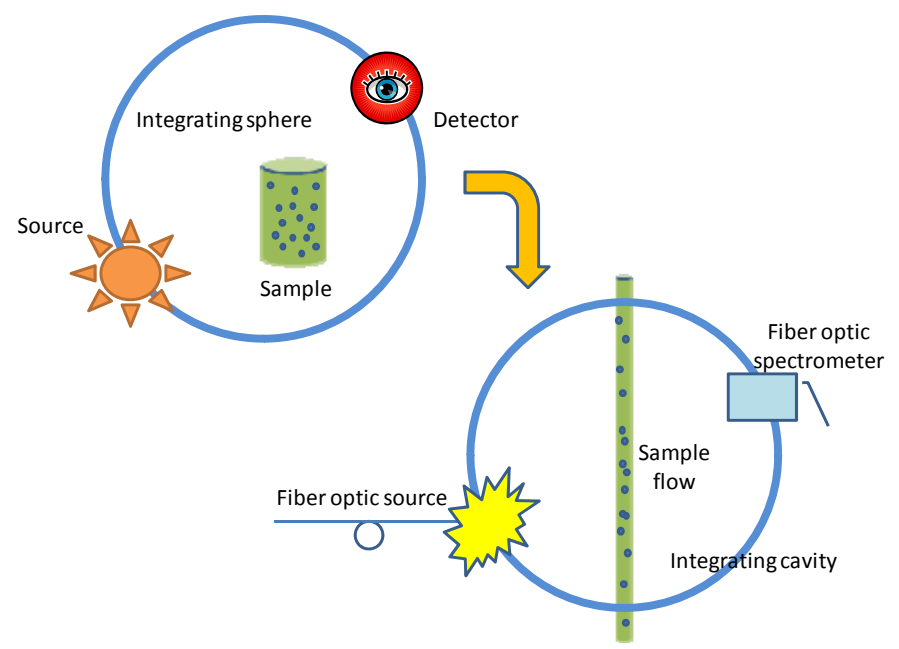

Fig. 13 - Possible implementation of the diffuse-light absorption spectroscopy setup by means of a flow cell for online monitoring during beer production

\footnotetext{
${ }^{12}$ M. Jackson, “Great beers of Belgium”, MMC 2001, page 122.
} 


\section{Appendix 1 - the beer collection}

\begin{tabular}{|c|c|c|c|c|c|c|}
\hline Country & Code & Brand & Class & Alcohol & $\begin{array}{c}\text { Turbidity } \\
\text { (NTU) }\end{array}$ & $\begin{array}{l}\text { Refractive } \\
\text { Index }\end{array}$ \\
\hline Belgium & VB01 & Oude Geuze Boon 2007 & Golden Lambic & $7,0 \%$ & 190,0 & 1,342 \\
\hline Belgium & VB02 & Oude Geuze Boon 2008 & Golden Lambic & $7,0 \%$ & 195,0 & 1,342 \\
\hline Belgium & VB03 & Den Herberg Blond & Golden Ale & $5,5 \%$ & 149,0 & 1,344 \\
\hline Belgium & VB04 & Den Herberg Tarwe & Weiss & $5,0 \%$ & 59,4 & 1,343 \\
\hline Belgium & VB05 & Gueuze Girardin & Golden Lambic & $5,0 \%$ & 135,0 & 1,341 \\
\hline Belgium & VB06 & Grimbergen & Golden Ale & $6,7 \%$ & 1,5 & 1,342 \\
\hline Belgium & VB07 & Hoegaarden & Weiss & $4,9 \%$ & 113,0 & 1,341 \\
\hline Belgium & VB08 & Palm & Golden Ale & $5,4 \%$ & 3,2 & 1,341 \\
\hline Belgium & VB09 & Satan Gold & Golden Ale & $8,0 \%$ & 48,7 & 1,343 \\
\hline Belgium & VB10 & Taras Boulba & Golden Ale & $4,5 \%$ & 125,0 & 1,341 \\
\hline Belgium & VB11 & Bersalis Tripel & Golden Ale & $9,5 \%$ & 10,2 & 1,347 \\
\hline Belgium & VB12 & Kriek Lindemans & Cherry Lambic & $3,5 \%$ & 24,4 & 1,349 \\
\hline Belgium & VB13 & Affligem & Golden Ale & $6,8 \%$ & 19,4 & 1,343 \\
\hline Belgium & VB14 & Kessel & Golden Ale & $7,5 \%$ & 20,9 & 1,341 \\
\hline Belgium & VB15 & Servais & Golden Ale & $5,5 \%$ & 67,7 & 1,342 \\
\hline Belgium & VB16 & Hof ten Dormaal & Golden Ale & $8,0 \%$ & 712,0 & 1,344 \\
\hline Belgium & VB17 & Oude Kriek Boon & Cherry Lambic & $6,5 \%$ & 147,0 & 1,343 \\
\hline Belgium & L01 & Bink & Golden Ale & $5,5 \%$ & 8,4 & 1,343 \\
\hline Belgium & L02 & Ter Dolen & Golden Ale & $6,1 \%$ & 19,6 & 1,343 \\
\hline Belgium & L03 & Jessenhofke Tripel & Golden Ale & $8,0 \%$ & 41,0 & 1,342 \\
\hline Belgium & L04 & Sint Gummarus Tripel & Golden Ale & $8,3 \%$ & 19,6 & 1,343 \\
\hline Belgium & L05 & De Chokier & Dark Ale & $7,0 \%$ & 163,0 & 1,344 \\
\hline Belgium & L06 & Cristal 1928 & Lager & $5,8 \%$ & 3,5 & 1,340 \\
\hline Belgium & L07 & Maya (Jessenhofke) & Golden Ale & $6,0 \%$ & 90,0 & 1,342 \\
\hline Belgium & WV01 & Balthazar & Dark Ale & $8,9 \%$ & 392,0 & 1,344 \\
\hline Belgium & WV02 & Keyte Triple & Golden Ale & $7,7 \%$ & 35,2 & 1,344 \\
\hline Belgium & WV03 & Harlekijn & Golden Ale & $6,0 \%$ & 17,3 & 1,340 \\
\hline Belgium & WV04 & Alternatief & Golden Ale & $5,0 \%$ & 407,0 & 1,340 \\
\hline Belgium & WV05 & Bockor Pils & Lager & $5,2 \%$ & 7,9 & 1,340 \\
\hline Belgium & WV06 & Blauw Export (Bockor) & Lager & $5,2 \%$ & 7,4 & 1,340 \\
\hline Belgium & WV07 & Brugse Zot & Golden Ale & $6,0 \%$ & 7,9 & 1,342 \\
\hline Belgium & OV01 & Gentse Strop & Golden Ale & $6,9 \%$ & 25,2 & 1,342 \\
\hline Belgium & OV02 & Troubadour Blond & Golden Ale & $6,5 \%$ & 28,3 & 1,344 \\
\hline Belgium & OV04 & Vicaris Tripel & Golden Ale & $8,5 \%$ & 50,5 & 1,343 \\
\hline Belgium & OV05 & Valeir Extra & Golden Ale & $6,5 \%$ & 83,0 & 1,342 \\
\hline Belgium & OV06 & De Graal & Golden Ale & $8,0 \%$ & 35,8 & 1,339 \\
\hline Belgium & A01 & De Koninck Tripel & Golden Ale & $8,0 \%$ & 13,6 & 1,344 \\
\hline Belgium & A02 & Bienvenue de Montaigue Tripel & Golden Ale & $7,0 \%$ & 688,0 & 1,343 \\
\hline Belgium & A03 & Lucifer & Golden Ale & $8,0 \%$ & 10,2 & 1,342 \\
\hline Belgium & A04 & Gouden Carolus & Dark Ale & $8,5 \%$ & 17,5 & 1,347 \\
\hline Belgium & A05 & Karmeliet Tripel & Golden Ale & $8,4 \%$ & 22,9 & 1,347 \\
\hline Belgium & A06 & Malheur 6 & Golden Ale & $6,0 \%$ & 77,3 & 1,340 \\
\hline Belgium & A07 & Westmalle Tripel & Golden Ale & $9,5 \%$ & 22,0 & 1,343 \\
\hline Belgium & A08 & Duvel & Golden Ale & $8,5 \%$ & 54,4 & 1,343 \\
\hline Belgium & H01 & Magus Belgo & Golden Ale & $6,6 \%$ & 61,1 & 1,344 \\
\hline Belgium & H02 & Belgoo Luppoo & Golden Ale & $6,5 \%$ & 26,1 & 1,343 \\
\hline Belgium & H03 & Moinette Blond & Golden Ale & $8,5 \%$ & 14,7 & 1,341 \\
\hline Belgium & H04 & Ciney Blond & Golden Ale & $7,0 \%$ & 5,2 & 1,342 \\
\hline Belgium & N01 & Leffe Blond & Golden Ale & $6,6 \%$ & 1,5 & 1,344 \\
\hline Belgium & LU01 & La Chouffe Blond & Golden Ale & $8,0 \%$ & 17,7 & 1,343 \\
\hline
\end{tabular}




\begin{tabular}{|c|c|c|c|c|c|c|}
\hline Italy & $\mathrm{I} 1$ & Moretti Baffo d'Oro & Lager & $4,8 \%$ & 3,4 & 1,340 \\
\hline Italy & $\mathrm{I} 2$ & Pedavena & Lager & $5,0 \%$ & 1,6 & 1,341 \\
\hline Italy & I3 & Ichnusa & Lager & $4,7 \%$ & 2,2 & 1,340 \\
\hline Italy & I5 & Poggio del Farro & Golden Ale & $5,5 \%$ & 86,9 & 1,343 \\
\hline Italy & I6 & Libra & Lager & $5,8 \%$ & 5,7 & 1,341 \\
\hline Italy & I7 & Peroni & Lager & $4,7 \%$ & 1,6 & 1,339 \\
\hline Italy & I8 & Tourtel & Lager & $0,5 \%$ & 1,3 & 1,340 \\
\hline Italy & I9 & Moretti Rossa & Doppelbock & $7,2 \%$ & 2,6 & 1,345 \\
\hline Italy & $\mathrm{I} 10$ & La Matta Ambrata & Dark Ale & $6,5 \%$ & 8,2 & 1,345 \\
\hline Italy & I11 & Glencoe & Dark Ale & $6,5 \%$ & 32,4 & 1,345 \\
\hline Italy & $\mathrm{I} 12$ & La Monella & Golden Ale & $5,0 \%$ & 20,7 & 1,342 \\
\hline Italy & $\mathrm{I} 13$ & La Biscara & Golden Ale & $7,2 \%$ & 67,5 & 1,345 \\
\hline Italy & $\mathrm{I} 14$ & Cosimo & Dark Ale & $5,1 \%$ & 237,0 & 1,341 \\
\hline Italy & $\mathrm{I} 15$ & Caterina & Golden Ale & $5,1 \%$ & 86,0 & 1,341 \\
\hline Italy & $\mathrm{I} 16$ & Menabrea \& Figli & Lager & $4,8 \%$ & 2,0 & 1,340 \\
\hline Germany & G1 & EKU 28 & Doppelbock & $11,0 \%$ & 3,4 & 1,351 \\
\hline Germany & G2 & HB Original & Lager & $5,1 \%$ & 1,5 & 1,340 \\
\hline Germany & G3 & $\mathrm{DAB}$ & Lager & $5,0 \%$ & 1,6 & 1,341 \\
\hline Germany & G4 & Warsteiner & Lager & $4,8 \%$ & 2,5 & 1,340 \\
\hline Germany & G5 & Beck's & Lager & $5,0 \%$ & 1,7 & 1,341 \\
\hline Germany & G6 & Franziskener Weisse & Weiss & $5,0 \%$ & 89,6 & 1,341 \\
\hline Germany & G7 & Riedenburger Weisse & Weiss & $5,4 \%$ & 37,4 & 1,342 \\
\hline Denmark & D1 & Ceres TOP Pilsener & Lager & $4,6 \%$ & 1,2 & 1,339 \\
\hline Denmark & D2 & Tuborg & Lager & $5,0 \%$ & 1,2 & 1,340 \\
\hline Denmark & D3 & Ceres Strong Ale & Golden Ale & $7,7 \%$ & 1,4 & 1,343 \\
\hline Denmark & D4 & Ceres Red Erik & Dark Ale & $6,5 \%$ & 1,0 & 1,341 \\
\hline Denmark & D5 & Ceres Old 9 & Lager & $9,1 \%$ & 1,1 & 1,341 \\
\hline England & E1 & Ruddles County & Dark Ale & $4,7 \%$ & 1,4 & 1,341 \\
\hline England & E2 & Tennent's & Golden Ale & $9,0 \%$ & 1,9 & 1,345 \\
\hline Netherland & N1 & Bavaria 8.6 & Lager & $7,9 \%$ & 4,7 & 1,342 \\
\hline Japan & $\mathrm{J} 1$ & Asahi & Lager & $5,0 \%$ & 1,7 & 1,340 \\
\hline Japan & $\mathrm{J} 2$ & Kinin Ichiban & Lager & $5,0 \%$ & 2,0 & 1,339 \\
\hline Japan & $\mathrm{J} 3$ & Sapporo & Lager & $5,0 \%$ & 1,7 & 1,341 \\
\hline Czech & $\mathrm{Z1}$ & Budejovicky Budvar & Lager & $5,0 \%$ & 1,0 & 1,341 \\
\hline Cuba & C1 & Mayabe & Lager & $4,0 \%$ & 1,7 & 1,337 \\
\hline Mexico & M1 & Corona & Mexican & $4,6 \%$ & 2,1 & 1,341 \\
\hline
\end{tabular}

